\title{
DESIGN OF A CATHODIC PROTECTION SYSTEM TO PREVENT CORROSION OF METALLIC STRUCTURES USING HYBRID RENEWABLE ENERGY SOURCES
}

\author{
Ashraf I. EL-Alem ${ }^{1}$, Ahmed M. Azmy ${ }^{2}$, A. Hosam-Eldin ${ }^{3}$ \\ ${ }^{1}$ Electrical Maintenance Engineer, Egypt, ashraf.elalem@yahoo.com \\ ${ }^{2}$ Department of Electrical Power and Machines Engineering, Faculty of Engineering, Tanta \\ University, Tanta, Egypt, azmy.ahmed@hotmail.com \\ ${ }^{3}$ Electrical Engineering Department, Faculty of Engineering, Alexandria University, \\ a.hossamudn@gmail.com
}

\begin{abstract}
This paper presents a study to design a cathodic protection system to protect metallic structures against corrosion using hybrid renewable energy sources. The corrosion of pipelines and storage tanks may cause very dangerous situations such as spills, production interruption and destructions of surrounding environment ending with great explosions. An effective method is to use impressed current cathodic protection system to overcome corrosion. This method can be applied to real systems based on hybrid renewable energy sources. A generic program is developed to design the full system with all details to achieve the best performance including the d.c. source. The possibility of supplying the cathodic protection system by wind and/or small solar panel and few nickel cadmium batteries eliminating the external power is also researched. The results revealed the possibility of designing the impressed current cathodic protection system for different configurations. It will be also possible to obtain better performance for the system through increasing the life time of the system.

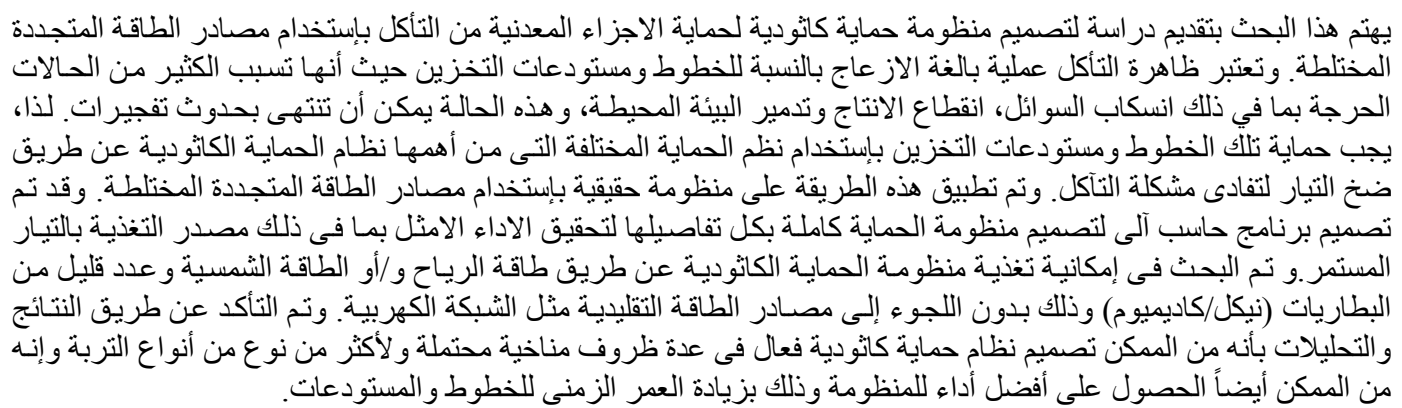

\section{INTRODUCTION}

Due to the increase of transportation and storage of petroleum projects in Egypt in the last few years, it became very important to secure the transfer and the storage of the products. This can be accomplished by protecting both pipelines and storage tanks from corrosion to prevent the loss of transmitted objects through the pipelines. Allowing the corrosion in either pipelines or storage tanks will cause critical situations including spills, production interruption and destructions of surrounding environment. The situation can finally end with explosions. One scheme for corrosion protection depends on utilizing impressed current cathodic protection system [1].

By definition, corrosion is a process in which metals return to their oxidized forms [2]. It is also possible to define corrosion as the degradation of a material through environmental interaction leading to the damage of metals [3]. A practical active method is to use impressed current cathodic protection system to overcome corrosion using a transformer rectifier as a 
d.c. power source [4]. However, this method is not economic for metallic protection in remote areas such as deserts. In this case, the ac power source, which is then converted to the d.c. form using a rectifier, is commonly unavailable [5].

To overcome the abovementioned problems, a hybrid renewable energy-based source can be used as a d.c. power supply. The system is designed using a generic program considering all details to define the best parameters of the system. The outputs include the best number of anodes, best weight of coke breeze and best rating of the d.c. source that will energize this cathodic protection system.

In [6], the research introduced an application of nickel-coated carbon fiber material in cathodic protection of underground-buried steel structures. On the other hand, the research introduce in [7] investigated the effect of alternating current on cathodic protection of pipelines. However, the type of the d.c. power supply used to feed the cathodic protection system is not investigated in these researches. In addition, the studies did not include the design of the cathodic protection system for the protected structure.

In [8], the focus was to prolong the lives of buried crude-oil and natural-gas pipelines by cathodic protection. The search discussed the design of the pipeline cathodic protection system from the point of view of hydraulics and mechanics such as pipe diameter, Reynolds number, friction factor for pipeline and pipeline wall thickness. Feeding the cathodic protection system was based on conventional sources. The research discussed the design of sacrificial (galvanic) cathodic protection that has no external power source and is applied only on good-quality coating for new pipelines with short life periods. Also, the galvanic system is limited to systems with relatively low current requirements, typically below $500 \mathrm{~mA}$.

In [9], the research introduced a simulation of cathodic protection potential distributions on oil well casings. The research discussed the design of the cathodic protection system only from the point of view of potential distribution along the well casing. In addition, the corrosion phenomenon was not defined clearly.

This paper investigates the problem of metallic structure corrosion and provides a design of a cathodic protection system to prevent its occurrence. The design includes the use of renewable energy sources such as solar, wind and hybrid wind-solar to feed the cathodic protection system. Additionally, the paper discusses a generic design of an impressed current system with different values of the inputs. Thus, it will be possible to change the system parameters such as pipeline diameter, system life time, pipeline length, anode type and its dimensions to get the corresponding outputs such as number of anodes, spacing between anodes, rated power and weight of coke breeze. The impressed current can be applied to systems with high current requirements up to $60 \mathrm{~A}$ depending on the design and operating conditions.

\section{PROBLEM STATEMENT}

Corrosion is an electrochemical oxidation reaction that requires an anode, a cathode, an electron pathway and an electrolyte to take place. The complete system comprising these components is called a corrosion cell as shown in Fig. 1 [2]. The process of corrosion is mostly a nuisance since it leads to the damage of metals and must be prevented from taking place. This is often the case in buried metallic structures such as pipelines, oil storage tanks, oil and gas wells, offshore structures, seagoing ship hulls, marine pilings, water tanks and some chemical equipment [10].

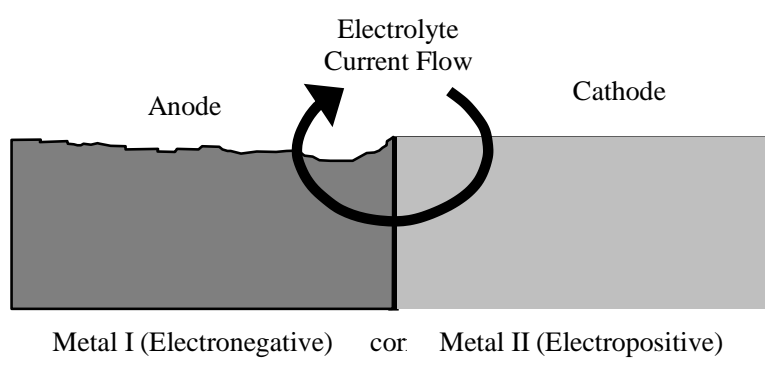

There are two basic ways by which corrosion can occur, general corrosion (chemical in nature) and electrochemical corrosion.

\section{A. General Corrosion}

General corrosion is purely chemical in nature. The general corrosion process is extremely slow and is dependent on the ion concentration of the electrolyte to which the structure is exposed. It is a very mild form of corrosion and is typically uniform over the surface of an exposed metal. In general corrosion, failures of pipes or tanks do not occur quickly since no pitting or penetration of the structure occurs, rather, it only causes surface corrosion.

General corrosion can become significant only under very extreme conditions (acidic electrolyte). However, the metal is not completely uniform and the electrolyte is not completely homogeneous. This 
results in electrochemical corrosion cells, which greatly overshadows general corrosion.

\section{B. Electrochemical Corrosion}

A more destructive form of corrosion is caused by the formation of a corrosion cell, which is an electrochemical process. The area of higher potential (less negative) is the cathode and the area of lower potential (more negative) is the anode. The anode and cathode must be in an electrically conducting medium. The medium (called an electrolyte) can be soil, water, or any other chemically suitable material. When these conditions exist, direct current flows between the anode and the cathode. The anode loses metal ions to the electrolyte and corrodes (or dissolves).

To form an electrochemical corrosion cell, there must be a difference in potential between two different metallic structures or between one part of a metallic structure and the other. This potential difference can be caused by many factors but commonly it results from the use of dissimilar metals, such as copper and steel. In addition, there must be a metallic path electrically connecting the anode and the cathode.

In order to prevent anodic reactions from occurring due to electrochemical reactions on that metal, electrons must be prevented from leaving the metal. The anodic reaction on the metal to be protected can be effectively prevented, and thus corrosion is avoided, by connecting the metal to be protected to a more negative source. Thus, the flow of electrons is from the external source to the metal being protected. The commonly-used methods to prevent corrosion are highlighted in the following sections:

\section{A. Material Selection}

The use of special materials such as stainless steels and plastics can provide better resistance to corrosion to enhance the life span of a structure. Also, alloying may resist corrosion but this has the disadvantage of high cost of used materials.

\section{B. Coatings and Liners}

In this method; coating surfaces is widely used for protecting the surfaces. The disadvantage of using coating and liners method alone is the deterioration of coating due to bad weather and high level of humidity.

\section{Corrosion inhibitors}

When chemical additives are added to a corrosive environment, the rate of attack is decreased. The inhibitors can extend the life of equipment, prevent system shutdowns and failures, avoid product contamination, prevent loss of heat transfer, and preserve structural finishes. However, this method only protects the internal surfaces for the object from corrosion and don't protect the external surfaces.

\section{Cathodic Protection (CP)}

$\mathrm{CP}$ consists of deliberate methods, which use selected materials and/or application of direct electrical current to counteract the normal corrosion of a structure that contains metal. The fundamental principle of $\mathrm{CP}$ is the application of a counter potential to prevent the electrochemical interchange of ions, which occurs in corrosion. Due to its importance, $\mathrm{CP}$ is the concerned method in this paper to prevent corrosion.

The impressed current cathodic protection system is used in a wide range of applications to protect the underground pipelines, tanks and the hulls of ships. The negative terminal of a d.c. current source is connected to the protected metal and its positive terminal is connected to a sacrificial anode existing in the same medium to close the electric circuit. The metallic structure is charged by electric current with more electrons and hence the electrode potential will be changed to the negative polarity.

The d.c. source is supplied by a transformer rectifier or other d.c. power source such as a hybrid solarwind power source. The layout of an impressed current system is shown in Fig. 2.

The external current is injected into the soil (or electrolyte) via engineered anodes. The anodes of the impressed current system provide the means for the protective current to enter the electrolyte. Materials such as graphite, high silicon cast iron, platinum, or mixed metal oxides are used as anodes because they have a very low loss of weight per ampere-year.

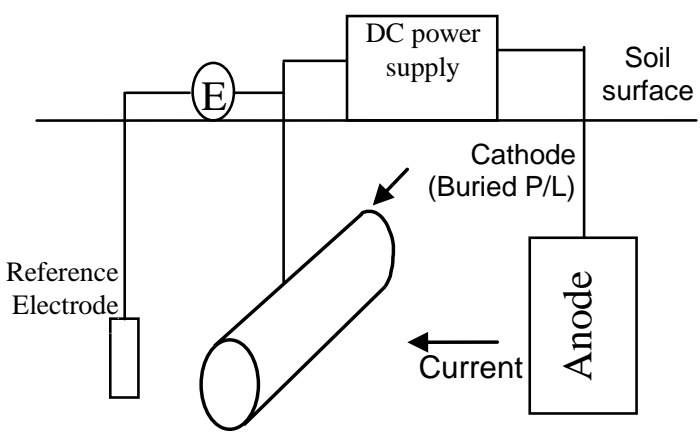

Fig. 2 Layout of an impressed current cathodic protection system

\section{Utilizations of Cathodic Protection}

The cathodic protection system can be simply utilized by providing a dc circuit and it can be monitored continuously. This system is widely applied to coated objects with different degrees of 
coating, such as pipelines and storage tanks, to provide corrosion control to spots located on the object, where the coating may be defected. Also, it may be applied to existing metallic objects to increase their expected lifetime.

When a decision is made to utilize the system of cathodic protection, there will be no need to use the principle of corrosion allowance to thin parts of pipelines and tanks that can be manufactured with high cost.

Components of impressed current system

A typical impressed current cathodic protection system consists of the following components:

- Relatively inert anode, anode bed and backfill

- Dc power source such as batteries, renewable energy resources ... etc.

- Test station and inter connecting cables

- Reference electrode

- Anode junction box

Factors Affecting Cathodic Protection System

The factors that affect the cathodic protection system are the coatings, the soils, the grounding and the electrical shielding and interference from other systems.

\section{METHODOLOGY}

The design of the cathodic protection system for pipeline and tank bottom is accomplished using the MATLAB package. The target is to design the cathodic protection system regarding ground bed resistance, spacing between anodes, number of anodes to be used, rated d.c. current, rated d.c. voltage, net weight of coke breeze, number of series cells and parallel rows of the cells, wind turbine rated power, number of series and parallel rows of batteries. These are considered as outputs from the design considering the constraints to keep the body, i.e. pipeline and tank bottom, protected for the entire lifetime of the cathodic protection system (about 20 years).

The required input data related to the anode are the anode length and diameter, backfill length and diameter, anode maximum current density, consumption rate and anode weight. Also, the design is related to the protected body such as tank diameter, pipeline length and diameter and the field survey data such as soil resistivity. Also, the type of coating with the corresponding current density is also required.

The steps of the design for pipeline and tank are described by the flowchart shown in Fig. 3.

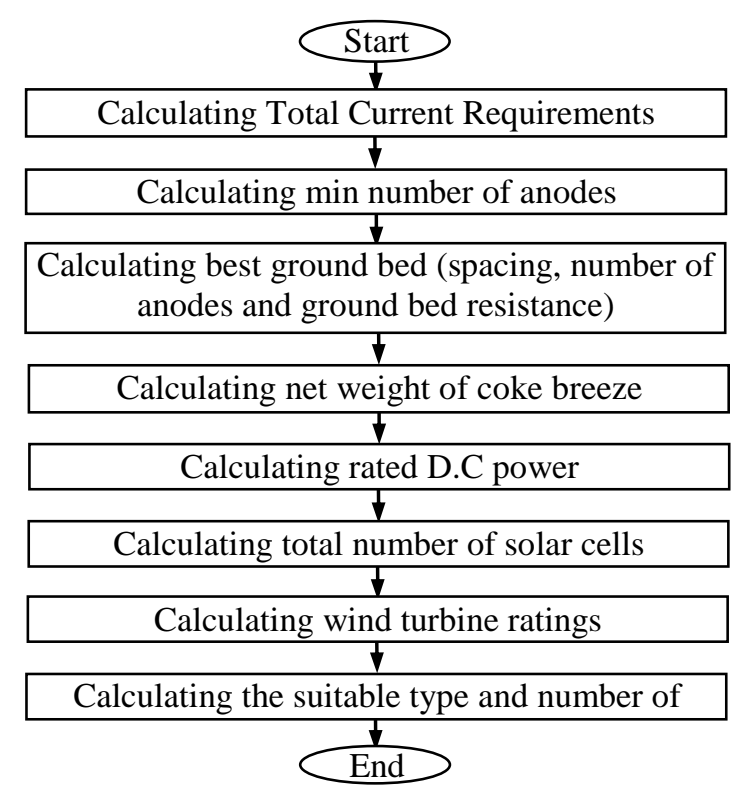

Fig. 3. The flowchart of the design steps for pipelines and tanks

For the pipeline design, the determination of the total current requirement of the system can be done by one of two ways:

1- If the total current requirement is known, the minimum number of anodes based on anode maximum current density is calculated.

2- If the total current requirement is not specified, it should be calculated by calculating the total surface area of the pipeline by using pipeline length and outer diameter. Then the current density is chosen according to the current density of different types of coating material.

The minimum number of anodes is calculated based on anode maximum current density as given by equation 2 in the discussion of tank design. Then, it is calculated once again based on anode consumption rate as given by equation 3 in the discussion of tank design. Thus, the greater number from the previous two values is selected as the minimum number of anodes used for the system. The next step is to calculate anode bed resistance for different spacing and different number of anodes. Thus, the number of anodes that maintain the ground bed resistance within the allowable range can be chosen and the smallest spacing corresponding to it can be estimated. Consequently, the number of anodes, anode ground bed resistance and spacing between anodes are defined as best values. The net weight of coke breeze is calculated using the coke breeze density and the best number of anodes as obtained in the previous steps.

The rated d.c. power to supply the protection system is estimated through the obtained value of the total 
current requirement and the voltage needed to drive that current. Then, the required number of solar cells to supply the d.c. power of the system is obtained. It is also essential to choose standard voltage of the wind turbine based on the defined system voltage. The rated power of the wind turbine is also derived using the standard power values. Finally, the suitable type of batteries for supplying the system power and the total number of batteries are defined.

From the previous steps, the final outputs are extracted including the best values of the following: ground bed resistance, number of anodes and spacing between them, rated current and voltage, net weight of coke breeze, number of series and parallel solar cells, rated voltage and power of the wind turbine and number of series and parallel batteries.

The actual data for a real installed system in western desert located in Egypt are used as follows:

1. Diameter: $30.48 \mathrm{~cm}$

2. Length: $14,000 \mathrm{~m}$

3. Surface Area: $13405.8 \mathrm{~m}^{2}$

4. Current Density: $0.5 \mathrm{~mA} / \mathrm{m}^{2}$

5. Cathodic Protection Life time: 20 years

6. Soil Resistivity: $3000 \mathrm{ohm}-\mathrm{cm}$

7. Allowable Ground Bed Resistance: 1 ohm

8. Used Anodes: iron silicon anodes

9. Anode Length: $152 \mathrm{~cm}$

10. Anode Diameter: $7.5 \mathrm{~cm}$

For the tank design, the radius of the circle, where the anodes are going to be placed around the tank is obtained to maintain the voltage shift under the tank bottom. The calculation of the current requirement of the system, if not specified, is accomplished through the following steps:

1. The total surface area of the tank bottom is calculated using tank outer diameter.

2. The current density is defined as $20 \mathrm{~mA} / \mathrm{m}^{2}$ or a special current density is selected to be used in calculations.

The current value that gives the desired voltage shift under the tank bottom is also calculated and the higher value of current from the previous two steps is chosen and set as the required current. The calculation of the minimum number of anodes is based on three factors: maximum anode spacing, anode maximum current density and anode consumption rate.

The minimum number of anodes is calculated using three methods:

1. Depending on anode's spacing using the equation

$$
N_{\text {tan k1 }}=\frac{C_{\text {anodes }}}{100 S_{\max }}
$$

where $\mathrm{N}_{\text {tank1 } 1}$ is the number of required anodes, Canodes is circumference of anodes circle around tank and Smax is the maximum spacing between anodes.

2. Depending on anode's maximum current density:

$$
N_{\text {mcd1 }}=\frac{1200 I}{\pi d L G}
$$

where $\mathrm{N}_{\mathrm{mcd} 1}$ is the number of required anodes, $\mathrm{I}$ is the current required by the cathodic protection system, $\mathrm{d}$ is the anode diameter, $\mathrm{L}$ is the anode length and $\mathrm{G}$ is the anode maximum current density.

3. Depending on anode's consumption rate:

$$
N_{\text {acrl }}=\frac{1.2 I Y C}{W}
$$

where $\mathrm{N}_{\mathrm{acr} 1}$ is number of required anodes, $\mathrm{I}$ is the current required by the cathodic protection system, $\mathrm{Y}$ is the life time of the system, $\mathrm{C}$ is anode consumption rate and $\mathrm{W}$ is the anode weight.

The three values are compared and the greater number is selected as the minimum number of anodes to be used in the following steps in the design.

The other steps are similar to those used to design the pipelines. Similar to the previous case, actual data are used to describe the installed system for tank bottom as follows:

1. Tank diameter: $8 \mathrm{~m}$

2. Tank circumference: $25.13 \mathrm{~m}$

3. Tank area: $50.26 \mathrm{~m}^{2}$

4. Anodes circle diameter: $10 \mathrm{~m}$

5. Anodes circle circumference: $31.41 \mathrm{~m}$

6. Current density: $5 \mathrm{~mA} / \mathrm{m}^{2}$

7. Cathodic protection life time: 20 years

8. Soil resistivity: $3000 \mathrm{ohm}-\mathrm{cm}$

9. Allowable ground bed resistance: $2.5 \mathrm{ohm}$

10. Used anodes: iron silicon anodes

11. Anode length: $152 \mathrm{~cm}$

12. Anode diameter: $7.5 \mathrm{~cm}$

The two case studies for pipeline and tank bottom are re-designed using the developed program and a comparison is given in the following section.

\section{RESULTS AND DISCUSSION}

The output results from the design program for cathodic protection system for pipelines are divided into five groups:

1. Cathodic Protection System Design:

Best number of anodes: 11 anodes

Best spacing between anodes: $6.5 \mathrm{~m}$ 
Best ground bed resistance when using these anodes: $0.997 \Omega$

Net weight of coke breeze used as backfill: $540.74 \mathrm{~kg}$

2. Conventional d.c. source:

The rating of the conventional d.c. power source to supply the protection system is $24 \mathrm{~V}$ and $25 \mathrm{~A}$, which can be achieved using a suitable transformer rectifier unit. According to the introduced design, the calculated power is higher than the power of the actual system. The higher power in this case is allowed regarding the higher current density of 1.25 $\mathrm{mA} / \mathrm{m}^{2}$ selected according to the British standard to achieve maximum protection for the pipeline and to have reserve power for further modification.

3. Only solar modules are used to feed the system:

Based on rated quantities of $0.5 \mathrm{~V}$ and $2 \mathrm{~A}$ per module, the total number of modules needed for supplying the protection system is 4032 module arranged in 84 parallel and 48 series modules.

4. Only a small wind turbine is used to feed the system:

The required small wind turbine for supplying the system operates at $24 \mathrm{~V}$ with a rating of 860 watt working at wind speeds around $10 \mathrm{~m} / \mathrm{s}$ and its cut in speed is $3 \mathrm{~m} / \mathrm{s}$.

5. A hybrid system is used to feed the system:

In this case, a hybrid system consisting of wind and solar cells is used to supply the protection system. Based on rated quantities of $0.5 \mathrm{~V}$ and $2 \mathrm{~A}$ per solar module, the total number of modules needed is 2400 module arranged in 50 parallel and 48 series modules. The required small wind turbine unit is a $24 \mathrm{~V}$ with a rating of 460 watt.

The current required by the cathodic protection system is the same regardless of the feeding source. The individual units in the hybrid system, the wind turbine and the solar cells, will contribute together in supplying this current in the hybrid configuration. Therefore, the reduction of the current supplied by the wind turbine and the solar cells can result in reduced capacities of the units in the hybrid configuration.

6. Batteries:

With nickel cadmium batteries with $1 \mathrm{~V} /$ cell and a capacity of $530 \mathrm{Ah}$, the total number of batteries is 72. The series and parallel number of batteries are 24 and 3 respectively.

Table 1 summarizes the comparison between the design of the actual installed system and the proposed design for pipeline cathodic protection system.

From this table, it is obvious that the proposed number of anodes is slightly higher than the actual number in the installed system. Regardless of the additional cost of anodes, this will give better economic and technical condition for the system due to the expected increase in the lifetime of the system. Furthermore, the external power is eliminated since the power will be supplied by using small solar panel and few nickel cadmium batteries. The wind energy can be used in winter at wind speeds around $10 \mathrm{~m} / \mathrm{s}$, while the wind speed at the rest of the year will not exceed $4.5 \mathrm{~m} / \mathrm{s}$. Therefore, the wind power is not preferred to be used. However, if the wind speed is higher all around the year, the wind down time can be overcome by using storage batteries similar to that used with the solar panel.

Table (1): Comparison between the actual design and the proposed design for pipeline cathodic protection system

\begin{tabular}{|c|c|c|c|}
\hline $\begin{array}{l}\text { Comparison } \\
\text { Items }\end{array}$ & $\begin{array}{l}\text { Actual } \\
\text { installed } \\
\text { system }\end{array}$ & $\begin{array}{l}\text { Proposed design } \\
\text { with separate } \\
\text { supply system } \\
\text { (solar or wind) } \\
\end{array}$ & $\begin{array}{l}\text { Proposed design } \\
\text { with hybrid supply } \\
\text { system (solar and } \\
\text { wind) }\end{array}$ \\
\hline Anode type & $\begin{array}{l}\text { iron silicon } \\
\text { anodes }\end{array}$ & $\begin{array}{l}\text { iron silicon } \\
\text { anodes }\end{array}$ & iron silicon anodes \\
\hline $\begin{array}{l}\text { Number of } \\
\text { anodes }\end{array}$ & 9 & 11 & 11 \\
\hline $\begin{array}{l}\text { Spacing } \\
\text { between } \\
\text { anodes }\end{array}$ & Random & $\begin{array}{l}6.5 \mathrm{~m}, \text { to satisfy } \\
\text { the allowable } \\
\text { ground bed } \\
\text { resistance. }\end{array}$ & $\begin{array}{l}6.5 \mathrm{~m} \text {, to satisfy the } \\
\text { allowable ground } \\
\text { bed resistance. }\end{array}$ \\
\hline $\begin{array}{l}\text { Coke breeze } \\
\text { amount }\end{array}$ & Not known & $540.74 \mathrm{~kg}$ & $540.74 \mathrm{~kg}$ \\
\hline $\begin{array}{l}\text { Rated d.c. } \\
\text { power }\end{array}$ & $\begin{array}{l}24 \mathrm{~V} \text { and } \\
20 \mathrm{~A}\end{array}$ & $24 \mathrm{~V}$ and $25 \mathrm{~A}$ & $24 \mathrm{~V}$ and $25 \mathrm{~A}$ \\
\hline Solar Panel & $\begin{array}{l}\text { Not } \\
\text { installed }\end{array}$ & $\begin{array}{l}0.5 \mathrm{~V}, 2 \mathrm{~A} \\
\text { modules are } \\
\text { proposed } \\
84 \text { parallel and } 48 \\
\text { series modules } \\
\text { are proposed } \\
\end{array}$ & $\begin{array}{l}0.5 \mathrm{~V}, 2 \mathrm{~A} \text { modules } \\
\text { are proposed } \\
50 \text { parallel and } 48 \\
\text { series modules are } \\
\text { proposed }\end{array}$ \\
\hline Wind turbine & $\begin{array}{l}\text { Not } \\
\text { installed }\end{array}$ & $\begin{array}{l}\text { Rated power is } \\
860 \text { watt at } 24 \mathrm{~V}\end{array}$ & $\begin{array}{l}\text { Rated power is } 460 \\
\text { watt at } 24 \mathrm{~V}\end{array}$ \\
\hline Batteries & $\begin{array}{l}\text { Not } \\
\text { installed }\end{array}$ & $\begin{array}{l}24 \text { series and } 3 \\
\text { parallel batteries } \\
\text { are used with } \\
1 \mathrm{~V} / \text { cell, } 530 \mathrm{Ah} \\
\text { each }\end{array}$ & $\begin{array}{l}24 \text { series and } 3 \\
\text { parallel batteries } \\
\text { are used with } \\
1 \mathrm{~V} / \text { cell, } 530 \text { Ah each }\end{array}$ \\
\hline
\end{tabular}

For pipeline cathodic protection system, the rating of the wind turbine in the hybrid system is about $53.48 \%$ of the rating of wind turbine used separately. At the same time, the solar modules in the hybrid system have a capacity of about $59.52 \%$ of the separate solar modules. However, the entire hybrid unit has a rating of 3.32 times the rating of separate wind turbine and about $70.93 \%$ of the separate solar modules. Thus, the hybrid unit can be more expensive compared to the separate wind turbine but cheaper than the separate solar modules.

To study the effect of pipeline lengths and the number of anodes, the design is repeated with 
different values of the length starting from $14 \mathrm{~km}$ up to $45 \mathrm{~km}$ as shown in Fig. 4 .

It is obvious from this figure that the increase of the pipeline length requires increasing the number of anodes with almost the same ratio except for lower values of pipeline length. For pipeline lengths less than $20 \mathrm{~km}$, higher number of anodes per length will be required.

The second factor that affects the number of anodes is the pipeline lifetime. Fig. 5 shows the relation between the pipeline lifetime and the number of anodes.

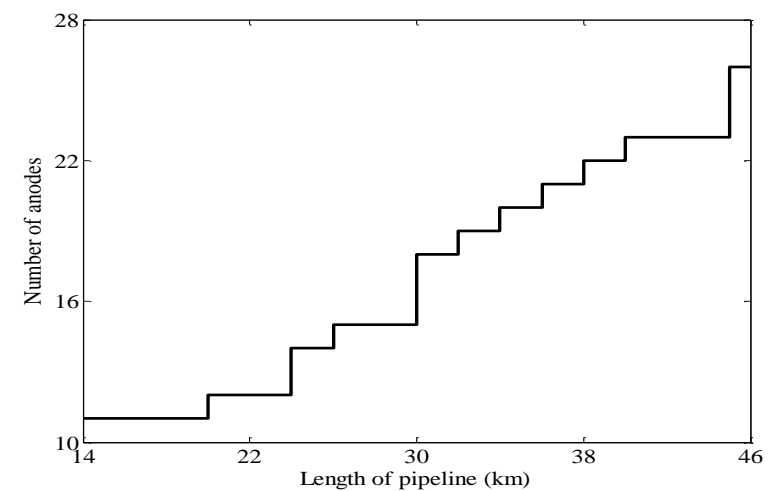

Fig. 4 Effect of pipeline length on the number of anodes

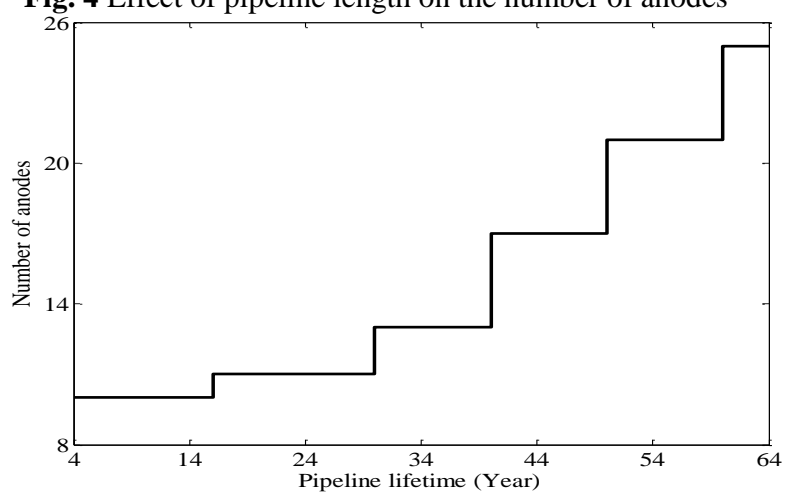

Fig. 5 Effect of pipeline lifetime on the number of anodes

Similar to the previous case, higher number of anodes per pipeline lifetime is required if the system is designed for lower lifetime. Therefore, it is more economic to design the system for operating lifetime more than 30 years.

The effect of pipeline diameters on the number of anodes has also to be investigated. Fig 6 shows the relation between the standard pipeline diameters and the number of anodes. In this case, the number of anodes per diameter is almost constant starting from a diameter of 25 inch. Lower than this value, the number of anodes per diameter will be very high.

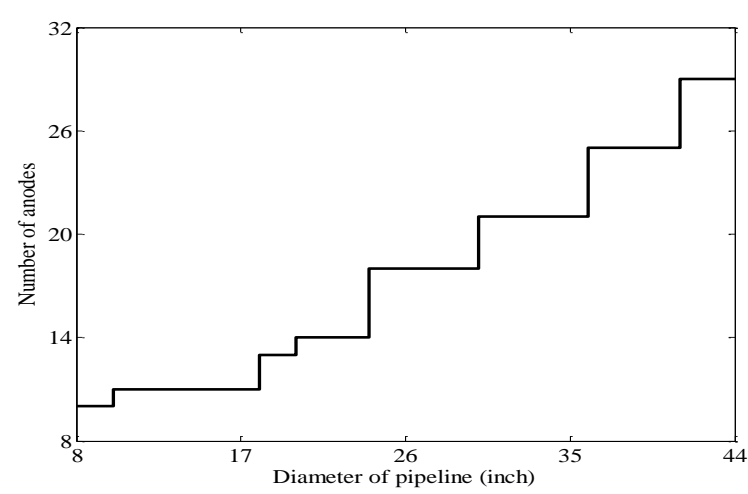

Fig 5 Effect of pipeline diameter on the number of anodes The outputs of the designed program for cathodic protection system for tank bottom are as follows:

1. Cathodic Protection Design:

Best number of anodes: 4 anodes

Best spacing between anodes: $7.854 \mathrm{~m}$

Best ground bed resistance when using these anodes: $2.3 \Omega$

Net weight of coke breeze used as backfill: $196.6 \mathrm{~kg}$

2. Conventional d.c. source:

The rating of the conventional d.c. supply in this case is a $12 \mathrm{~V}, 5 \mathrm{~A}$ d.c. source.

3. Only solar modules are used to feed the system: Assuming rated values of $0.5 \mathrm{~V}$ and $2 \mathrm{~A}$ per module, the total number of required modules is 408 modules arranged in 17 parallel and 24 series connected modules.

4. Only a small wind turbine is used to feed the system:

In this case, the required small wind turbine working at wind speeds around $10 \mathrm{~m} / \mathrm{s}$ and a cut in speed of 3 $\mathrm{m} / \mathrm{s}$ is rated at 460 watt at $12 \mathrm{~V}$.

5. A hybrid system is used to feed the system: Based on rated quantities of $0.5 \mathrm{~V}$ and $2 \mathrm{~A}$ per module, the solar modules have a total number of 408 module arranged in 17 parallel and 24 series modules. On the other hand, the required small wind turbine is a $12 \mathrm{~V}, 460$ watt unit.

It is obvious that the current required by the cathodic protection system is the same in case of separate units (solar or wind) and the hybrid configuration. In the hybrid configuration, the wind turbine and the solar cells will contribute in supplying this current together. Thus, the current required by each unit in the hybrid configuration is lower than that required by the separate unit. However, the design indicated that each unit in the hybrid system has the same rated power of the corresponding separate units. This means that the total rated power of the hybrid unit is higher than any individual unit alone.

Thus, the reduction of the current supplied by the wind turbine and the solar cells in the hybrid unit will 
not affect the rated value of these units. The reason is that the required current by the tank bottom when supplied by individual units in the hybrid system or separate units is lower than the minimum standard current and voltage. Consequently, the selected rated values are maintained at their minimum levels for all cases.

6. Batteries:

In this case, the nickel cadmium batteries with $1 \mathrm{~V} /$ cell and a capacity of $300 \mathrm{Ah}$ will have a total number of 12 batteries all connected in series.

Table 2 gives a comparison between the design of the actual installed system and the proposed design for tank bottom cathodic protection system.

The additional anode used according to the proposed design increases the initial cost of anodes but gives better general economic situation since it will increase the lifetime of the system. The renewable energy source will be responsible to supply the system without the need to external power source. Once again, the wind turbine can be used in winter at proper wind speeds. For higher average wind speeds, the turbine will be used all the year with the usage of the same battery designed with the solar panel.

Table (2): Comparison between the installed system and the proposed system for tank bottom cathodic protection

\begin{tabular}{|c|c|c|c|}
\hline $\begin{array}{l}\text { Comparison } \\
\text { Items }\end{array}$ & $\begin{array}{c}\text { Actual } \\
\text { installed } \\
\text { system }\end{array}$ & \begin{tabular}{|c|} 
system \\
Proposed \\
design with \\
separate \\
supply system \\
(solar or wind)
\end{tabular} & $\begin{array}{c}\text { Proposed design } \\
\text { with hybrid supply } \\
\text { system (solar and } \\
\text { wind) }\end{array}$ \\
\hline Anode type & $\begin{array}{l}\text { iron silicon } \\
\text { anodes }\end{array}$ & $\begin{array}{|ll|}\begin{array}{l}\text { iron } \\
\text { anodes }\end{array} & \text { silicon } \\
\end{array}$ & iron silicon anodes \\
\hline $\begin{array}{l}\text { Number of } \\
\text { anodes }\end{array}$ & \begin{tabular}{|l|}
3 \\
\end{tabular} & 4 & 4 \\
\hline $\begin{array}{l}\text { Spacing } \\
\text { between } \\
\text { anodes }\end{array}$ & $10.275 \mathrm{~m}$ & $7.854 \mathrm{~m}$ & $7.854 \mathrm{~m}$ \\
\hline $\begin{array}{l}\text { Coke breeze } \\
\text { amount }\end{array}$ & Not known & $196.6 \mathrm{~kg}$ & $196.6 \mathrm{~kg}$ \\
\hline \begin{tabular}{|l|l|} 
Rated d.c. \\
power
\end{tabular} & $12 \mathrm{~V}$ and $4 \mathrm{~A}$ & $12 \mathrm{~V}$ and $5 \mathrm{~A}$ & $12 \mathrm{~V}$ and $5 \mathrm{~A}$ \\
\hline Solar Panel & Not installed & $\begin{array}{lr}0.5 \mathrm{~V}, & 2 \mathrm{~A} \\
\text { modules } & \text { are } \\
\text { proposed } & \\
17 \text { parallel } & \text { and } \\
24 & \text { series } \\
\text { modules } & \text { are } \\
\text { proposed } & \end{array}$ & $\begin{array}{l}0.5 \mathrm{~V}, 2 \mathrm{~A} \text { modules } \\
\text { are proposed } \\
17 \text { parallel and } 24 \\
\text { series modules are } \\
\text { proposed }\end{array}$ \\
\hline $\begin{array}{l}\text { Wind } \\
\text { Turbine }\end{array}$ & Not installed & $\begin{array}{l}\text { Rated power is } \\
460 \text { watt at } 12 \mathrm{~V}\end{array}$ & $\begin{array}{l}\text { Rated power is } 460 \\
\text { watt at } 12 \mathrm{~V}\end{array}$ \\
\hline Batteries & Not installed & $\begin{array}{l}12 \text { series and } 1 \\
\text { parallel } \\
\text { batteries } \\
\text { used are } \\
1 \mathrm{~V} / \text { cell, } 300 \mathrm{Ah} \\
\text { each }\end{array}$ & $\begin{array}{l}12 \text { series and } 1 \\
\text { parallel batteries are } \\
\text { used with } 1 \mathrm{~V} / \text { cell, } \\
300 \text { Ah each }\end{array}$ \\
\hline
\end{tabular}

The effect of varying the tank diameter on the number of anodes is illustrated in Fig 6.

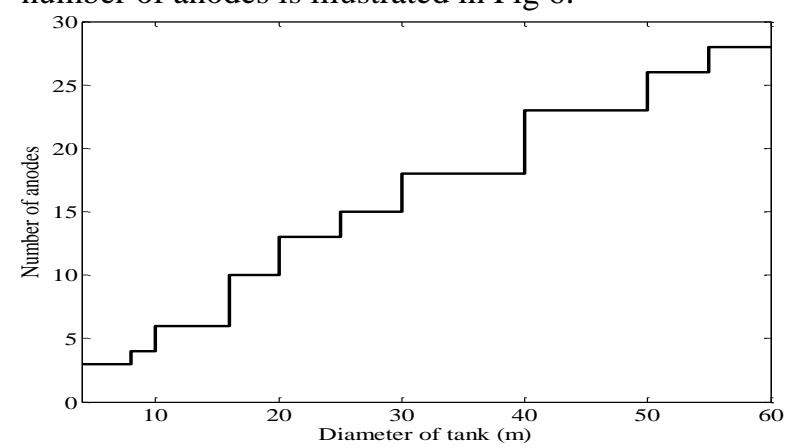

Fig. 6. Effect of tank diameter on the number of anodes

The relation is almost linear for all values of the tank diameter. On the other hand, the variation of the tank system lifetime does not affect the number of anodes, where four anodes are required in all cases for different lifetimes. This is attributed to the selection of the greater value among three values as explained in the tank design process in section 3.

Since the already existing pipeline and tank systems are located far from each other, each system has to be separately supplied with d.c. power source either by conventional sources or by solar or wind or hybrid units. On the other hand, if both pipeline and tank systems are located in the same area, both systems can be supplied using one power source as follows:

1. Using solar system based on rated quantities of $0.5 \mathrm{~V}$ and $2 \mathrm{~A}$ per module, the total number of modules to supply both pipeline and tank systems is 4400 module.

2. Since the total power required by the two systems is 660 watt, the nearest small wind turbine in the design to supply the above mentioned power is 860 watt.

For the same power required by the pipeline and tank systems, it is noticed that the rated power of the solar units is higher than the rated power of the wind turbine. This is attributed to taking into account the number of hours of daily sun insulation.

\section{CONCLUSION}

Based on the obtained results and discussion, the following points can be concluded:

1. The number of anodes calculated by the developed program is slightly higher than the actual number of anodes in the existing installation. Regardless of the cost of additional anodes, this will give better performance for the system due to the increase of the expected lifetime of the system. 
2. Increasing the pipeline diameter, pipeline system life time and pipeline length increases the number of used anodes of the cathodic protection system.

3. Increasing the tank diameter increases the number of anodes of the cathodic protection system. On the other hand, the variation of the tank system lifetime does not affect the number of anodes, where four anodes are required in all cases for different lifetimes.

4. The hybrid system used to supply cathodic protection system can be more expensive compared to separate wind turbine, while it can be more economic than separate solar cells.

5. The solar cells are more flexible and can be used with different rating values. They are more suitable for small power applications, while the wind turbines are not the best choice since they operate better at high wind speeds to produce large power. Therefore, solar cells are preferred compared to wind turbines for this application.

6. If the wind speed in the site is high enough to be used, the wind turbine can be a good choice to produce large power that can be used to supply more than one cathodic protection system.

7. Renewable energy is useful and economic enough to be used for pipelines that are laid underground for long distances because this will secure power for the cathodic protection system all over the year.

\section{REFERENCES}

[1] Engineering Encyclopedia of Saudi Aramco Standards, "Design Criteria of Cathodic Protection Systems", 2008, pp.1-64

[2] G. Kakuba, "Master Thesis of the Impressed Current Cathodic Protection System", Technische Universiteit Eindhoven Department of
Mathematics and Computer Science, 2005, pp.195

[3] D. L. Basham, J. W.Wright, K. I. Ferguson and G.W. Moy, "Operation and Maintenance of Cathodic Protection Systems", Unified Facilities Criteria (UFC), Department of Defence USA, 2003, pp. 1-220

[4] A.W. Peabody, "Control of Pipeline Corrosion", National Association of corrosion Engineers, 1967, pp. 1-347

[5] NACE International Standard, "Cathodic Protection Systems", National Association of Corrosion Engineers, Chapter 2, July 2008, pp. 187

[6] B. Pierozynski, J. Jankowski and W. Sokolski, "Application of Nickel-Coated Carbon Fibre Material in Cathodic Protection of UndergroundBuried Steel Structures", Corrosion Science, Volume 51, Issue 11, November 2009, pp. 26052609

[7] L.Y. Xu, X. Su and Y.F. Cheng, "Effect of Alternating Current on Cathodic Protection on Pipelines", Corrosion Science, Available online 5 October 2012

[8] M.T. Lilly, S.C. Ihekwoaba, S.O.T. Ogaji and S.D. Probert, "Prolonging the Lives of Buried Crude-Oil and Natural-Gas Pipelines by Cathodic Protection", Applied Energy, Volume 84, Issue 9, September 2007, pp. 958-970

[9] M.H. Parsa, S.R. Allahkaram and A.H. Ghobadi, "Simulation of Cathodic Protection Potential Distributions on Oil Well Casings", Journal of Petroleum Science and Engineering, Volume 72, Issues 3-4, June 2010, pp. 215-219

[10]Eur Ing R. L. Kean of ARK Corrosion Services and K. G. Davies, "Cathodic Protection", Corrosion Engineer, This is an update of a DTI publication first issued in 1981, pp. 1-8 